\title{
Entrepreneurial Intention of Entrepreneurial Student
}

\author{
Febrian Ulfa, Ayu Romadhani \\ School of Business and Management \\ Institut Teknologi Bandung \\ Bandung, Indonesia \\ febrian.ulfa@sbm-itb.ac.id
}

\begin{abstract}
It said that a country need at least $5 \%$ of entrepreneur from total population. Currently Indonesia has less than 2\% entrepreneurs. Previous research states that entrepreneurial education in Universities is one of the influencing factors to nurture entrepreneur. As argued, the intention to behave entrepreneurially depends on the human individual. The literature usually study entrepreneurial intention with entrepreneur soon to be as informant. However, there is not sufficient study about entrepreneurial intention with entrepreneur as informant. The study has aim to investigated the effect of factors self-efficacy, risk taking propensity, knowledge and skill, and background of parent as determinants of entrepreneurial intention, study case in SBM ITB. The research using both analysis: Quantitative and Qualitative. Quantitative analysis use a questionnaire as data collection tool. The questionnaire spread to 80 students of Entrepreneurial Program SBM ITB batch 2013 and 2014, using Microsoft Excel, SPSS version 22.0, and processed through Multi Linier Regression. Besides quantitative analysis, the research also use Qualitative using Semi Structured Interview. The interview also conducted to conform the result of quantitative analysis. The findings founded that overall Entrepreneurial Intention of Entrepreneurial Student affected the most by Self Efficacy. Risk Taking and Knowledge and Skill has quite significance to Entrepreneurial Intention. While Background of parent has no significance relation to Entrepreneurial Intention. Detail findings related to each factor will be discussed furthermore.
\end{abstract}

Keywords: entrepreneurial intention, self-efficacy, risk taking, knowledge and skill, background of parents,

\section{INTRODUCTION}

Entrepreneurship known on early 18 century in order to growing and organization enlargement through innovation and creativity. Definition of entrepreneurship relatively different based on the focus, such as new organization creation(1), established new activity, opportunities exploration.(2), and deal with uncertainty. Ordinarily, entrepreneurship is process of creativity and innovation that carry high risk in produce added value of product for community and gain profit for entrepreneur itself. Entrepreneurship is the backbone of economy, or tailbone of economy, and it is an economic regulator for a nation. Etymologically, entrepreneurship is a value needed to established new enterprise (start-up phase) or a process in create something new (creative) and different (innovative)(1). The person who actuate all these function is called as an entrepreneur. Definition of entrepreneur according to Tarmudji, in Indonesian language comes from phrase "wirausaha", split out from word "wira" and "usaha". Wira means role model, while "usaha" means willingness. So, entrepreneur can be define as "a person who willing to do something advantageous and could be a role model for community". To be an entrepreneur, a person should has intention and tough soul to reach the business objective. Intention has proven to be the best predictor towards entrepreneurship performance. Entrepreneurial intention could be define as starting point of a long term business establishment process

Indonesia can't deny to a condition where lack of entrepreneur compared to nearby country. Minister of Cooperative and Small Medium Enterprise, Anak Agung Gede Ngurah Puspayoga reveal amount of Indonesian entrepreneur is $1.65 \%$ of total population. In Singapore, their entrepreneurs reach 7\%, Malaysia 5\%, Thailand. The sociologist, David McClelland claim, "A country could be prosperous if there are at least $2 \%$ of entrepreneur of total population". To be a prosperous country based on McClelland's perspective, Indonesia need more entrepreneur. The influence of entrepreneur education is considered as one of important factor to thrive the intention and attitude of entrepreneurship in youth generation. Previous research state that intention of entrepreneurship against college student is source of new born entrepreneur in future. Attitude and knowledge they have got will generate tendency to established new enterprises in future (3).

Pursuant to Thomas Zimmerer, one of factor to develop entrepreneurship in a country rely on University role through entrepreneurship founding and education. University should apply entrepreneurship curriculum that consider empirical method to encourage student with knowledge and experience of both hard skill and soft skill in order to develop intention of entrepreneurship. Previous research state that basically, research about entrepreneurship intention done by seeing three different aspect: behavioural characteristic, demographic characteristic, and environmental characteristic(3) .SBM ITB as education institution established entrepreneurship major since 2014. The vision of entrepreneurship major is to be an institution whose educate and graduate an entrepreneur independently, believe in power of knowledge and practical competence of business on 2015. Since established until now, there are 80 student enrolled. The curriculum of this major quite different with other majority. Each of individual required to established own business, the student can choose which established alone or together as partner, same or different 
major. Towards of previous statement, this research will focused on entrepreneurship student of SBM ITB. During these two years of establishment, observation suggest that business performance acceleration among one student to another is different. The determinant of business performance is lies on the entrepreneur. Of course, numerous factors may influence the performance.

Entrepreneurship major is new major in ITB. The management targeted to create outstanding yet passionate entrepreneurship independently. At this time, there are 80 students registered as entrepreneurship student. The students required to established new business, whether alone or join with friends as partner. There are more than 30 business founded by SBM ITB's entrepreneurship students. The performance of each business is different. The stability of one to another business is low. Some people is cross to another company, some people is change the business idea, and some people get problem in keep the business performance consistent. The performance showed by an entrepreneur affected by the intention of individual to develop the business. Therefore, intention of an entrepreneur take important part. Previous research said that the intention might influenced by some factors. The factors are numerous, so the researcher want to predict what factors might influence the entrepreneurial intention of entrepreneurship student of SBM ITB.

\section{A. Entrepreneurial Intention and Its Conceptual Concept}

\section{1) Definition of Entrepreneurial Intention}

The theory of planned behaviour is a broadening of the existing reasoned action theory.(4). The reasoned action theory state that central factor in theory of planned behaviour is individual intention in order to perform behaviour. Intention also shows how hard an individual dare to try, how much effort had planned to be done and it related to what's next behaviour to be done.

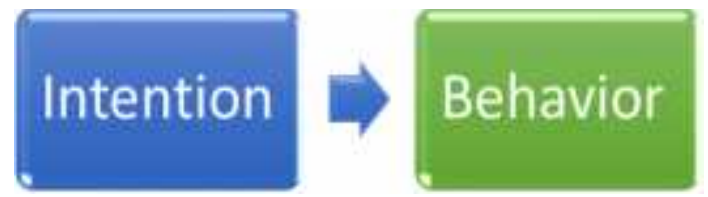

Based on the statement, it can conclude that the stronger intention in behaviour, the more likely performance should be good at. Also proved in his research that intention becomes important dimension towards showing behaviour(5). Likewise, of course there are several factors influenced the intention. But, TPB only use psychological determinant from an individual. Even though, a behaviour influenced also by demographic factors like gender, education background, age, experience that might be causes difference intention to be an entrepreneur. Thereby, the research will use factors found in prior research related entrepreneurial intention. Pursuant to Thomas Zimmerer, one of factor to develop entrepreneurship in a country rely on University role through entrepreneurship founding and education. University should apply entrepreneurship curriculum that consider empirical method to encourage student with knowledge and experience of both hard skill and soft skill in order to develop intention of entrepreneurship(6). The better education facilities and quality towards entrepreneurship, the student will more understand the advantage of being an entrepreneur. Prior empirical study proved there is positive impact from entrepreneurial education program in University level as initial new enterprise. University as highest level of education has opportunities to create new entrepreneur. Hence, entrepreneurial education has related to initiate entrepreneurial intention among students.

Numerous study had been done in order to dig a deeper knowledge and empirical study about entrepreneurial intention in entrepreneurial education. From Ramayah et al., (2005) in Endi (2011) use three indicators in predicting entrepreneurial intention in entrepreneurial education by:

- Desire to be an entrepreneur than work for a firm

- Entrepreneur as career option

- Planning to established a business

2) The intention's factor

Based on previous research, numerous factors that might influence a person to have entrepreneurial intention. The research will analyse the entrepreneurial intention with these variables:

\section{a) Self-Efficacy}

In previous research, (7) using entrepreneurial self-efficacy dimensions by De Noble et al. (1999). The dimensions entrepreneurial self-efficacy are:

- Developing new product and market opportunities : an individual belief to create a new products and to looking for opportunity

- Building an innovative environment: an individual belief to encourage environments, including friends or team to try a new idea or take initiative action.

- Initiating investor relationships : an individual belief to find sources of funds for the business

- Defining core purpose : an individual belief to communicate vision and manage the vision to friends/team/investors

- Coping with unexpected challenges : an individual belief to tolerate and deal with ambiguity and uncertainty in start up

- Developing critical human resources: an individual belief to recruit and retain potential individual to be partner/member/team of the business exist.

\section{b) Risk Taking Propensity}

Risk taking propensity could be determine to person's orientation regard taking chances in a decision making scenario The other definition (8), risk taking propensity is perceived probability of receiving rewards associated with success of a proposed situation, which required by an individual before himself will accept consequences of failure. According to Zhao et al., (2010) indicate there is positive relationship between risk taking propensity and entrepreneurial intention. 
Thus, an individual having higher risk-taking propensity will dare to take entrepreneurial activities. Risk-taking propensity is distinct from business to business or individual to individual, despite off without it, entrepreneurship would not become something allure as recent time. Risk Taking developed as an individual's tendency in order to taking chances in any decision-making case (9). Risk taking propensity can be define as perceived probability of receiving the consequences associated with success or failure proposed situation (Storey, 2000). Hung and Tangpong(10) generate General Risk Propensity Scale. This research will use this scale to measure risk taking propensity. General Risk Propensity has validated by several associates like financial risk propensity (Kapteyn and Teppa, 2002), social risk propensity (Weber et al., 2002), and gambling. Jawaorski and Kohli's risk propensity scale are business relevant. It has five items and addresses the role of risk propensity in market orientation influence. Then, Kuo (11) modified items to make them commonly applicable to business in general.

\section{c) Entrepreneurship Knowledge and Skill}

Entrepreneurial knowledge reflects to an individual's mentality and skills of an entrepreneur (12). The knowledge obtained can be acquired through consistent exposure to entrepreneurship activities. When a new enterprise had established, entrepreneur usually had well-educated, but lacks specific skills and knowledge about the market condition, finance, human resources, and other functions. When an entrepreneur lacks of knowledge, an entrepreneur need an education as "start-up education", usually concentrates on business-plan elaboration and orientation, visit to entrepreneurs and stakeholders supporter, or taking a guest speakers (Honig, 2004). Numerous methods in prior study to nurture an entrepreneur was developed. Linan et al., (13) found that awareness of being an entrepreneur, firm and growth development, creativity and innovation recognition, business environment knowledge are should implemented in all of education level. Entrepreneurial knowledge is one of important factors to act entrepreneurially. Linan's conception:

"the whole set of education and training activities-within the educational system or not- that try to develop in the participants the intention to perform entrepreneurial behaviours, or some of the elements that affect that intention, such as entrepreneurial knowledge, desirability of the entrepreneurial activity or its feasibility".

The indicator of an entrepreneur knowledge and skills measured by Muller (14):

- Business Planning acquirement

- Student orientation

- Entrepreneurial network

\section{d) Background of parents}

Family become foundation for children growth, in this phase which values nurtured. Value in term of creativity, innovation, responsibility, ethical, etc. Parents become role model for a child. Parker's (15) review is entrepreneurial parents might transform the taste of entrepreneurial through role modelling. A chance of becoming entrepreneur is 1.3 to 3 times bigger whose parents have been entrepreneur Support from family become one of key important to push an intention to be an entrepreneur(6)

\section{METHODOLOGY}

\section{Respondent}

This study involved the 2013 and 2014 semester undergraduate students in a university in an urban area in Indonesia which provide entrepreneurship courses in their curriculum. The total number of student participating in this study was 80 students in total, which considered of 40 students of 2013, and 40 students of 2014.

\section{Instrument}

To measure the factors influents Entrepreneurial Intention toward respondent, this study used questionnaire which modify from several literature consist of 28 items. The participants were asked to respond the items using Likert type scale $(1=$ strongly unimportant to $5=$ strongly important) based on the degree of their agreement with the statement. The higher the score they rate, the higher level of agreement they have. The lower the score they rate, the lower level of agreement they have. The reliability test showed that his scale was reliable to measure the Entrepreneurial Intention.

\begin{tabular}{|l|l|l|l|}
\hline No & \multicolumn{1}{|c|}{ Label } & \multicolumn{1}{|c|}{$\begin{array}{c}\text { Alpha } \\
\text { Cronbach }\end{array}$} & Reliability \\
\hline 1 & Self Efficacy & 0.803 & reliable \\
\hline 2 & Risk Taking & 0.589 & reliable \\
\hline 3 & Knowledge and Skill & 0.758 & reliable \\
\hline 4 & Background of Parent & 0.791 & reliable \\
\hline 5 & Entrepreneurial Intention & 0.923 & reliable \\
\hline
\end{tabular}

\section{RESULT}

\section{General Result}

Multiple Linear Regression is used to analyse the relationship between more than two independent variable with the dependent variable which be alleged with a mathematical and functional equation.

\begin{tabular}{|c|l|l|l|}
\hline $\mathbf{R}$ & R square & $\begin{array}{c}\text { Adjusted R } \\
\text { Square }\end{array}$ & Std. Error of the Estimate \\
\hline 0.645 & 0.416 & 0.385 & 0.37413 \\
\hline
\end{tabular}

Based on the table above, the $\mathrm{R}$ column represents the multiple correlation coefficient. $\mathrm{R}$ is considered to be one measure of dependent variable, in this case Entrepreneurial Intention. A value of 0.645 , in this case indicates a good level of prediction. The "R Square" column represent the coefficient of determinant, which is the proportion of variances in the dependent variable that can be explained by independent variables. The score of R Square above means the independent variables explain $41.6 \%$ of the dependent variable. 
Estimated model Coefficients

\begin{tabular}{|l|l|l|l|}
\hline \multicolumn{1}{|c|}{ Variable } & \multicolumn{1}{|c|}{$\begin{array}{c}\text { Coefficient } \\
\text { Regression }\end{array}$} & \multicolumn{1}{c|}{ t-score } & Sig \\
\hline Constant & 0.575 & 0.972 & 0.334 \\
\hline Self-Efficacy & 0.517 & 6.075 & 0.000 \\
\hline Risk Taking and & 0.089 & 0.618 & 0.539 \\
\hline $\begin{array}{l}\text { Knowledge of } \\
\text { Skill }\end{array}$ & -0.287 & 0.754 & 0.453 \\
\hline $\begin{array}{l}\text { Background } \\
\text { Parent }\end{array}$ & -1.698 & 0.094 \\
\hline
\end{tabular}

The general form of the equation to predict Entrepreneurial Intention from Self Efficacy, Risk Taking, Knowledge and Skill, and Background of Parent is:

$\mathrm{Y}=\mathrm{a}+\mathrm{b} 1 \mathrm{X} 1+\mathrm{b} 2 \mathrm{X} 2+\mathrm{b} 3 \mathrm{X} 3+\mathrm{b} 4 \mathrm{X} 4$

a: Constant

x1: Self Efficacy

$\mathrm{x} 2$ : Risk Taking

$\mathrm{x} 3$ : Knowledge and Skill

x4: Background of Parent

b1, b2, b3, b4: Regression coefficient

And by the output above, it can be applied as:

Entrepreneurial Intention $=0.575+(0.517 \mathrm{x}$ Self Efficacy $)$ $+(0.089 \times$ Risk Taking $)+(0.80 \times$ Knowledge and Skill $)-$ (0.287 x Background of Parent)

\section{CONCLUSION}

Current study showed that generally student intention to become entrepreneurial affected by self-efficacy (51\%) than other variable, risk taking, background of parent and knowledge and skill. Although this study didn't conduct pre and post test to see the effectiveness of entrepreneurship program, student in this study had established their own business although minimal 6 months / a semester. They also facilitated by academicians and business mentors in their curriculum. .Student should prepare business concept at $4^{\text {th }}$ semester, and learning by practice to create business planning and launch new product at $5^{\text {th }}$ semester. The student need to maintain the resources, the risk happened during business process and the result by their own. Every finale exam of each semester is about their business progress related target they set at early semester. Thus, all study methodology in order to create nascent entrepreneur to be ready in the real world of business and entrepreneurial

The result show that self-efficacy is the highest variable which affect entrepreneurial intention rather than other variable. Self-efficacy here means a belief of person in order to act and behave like an entrepreneur in process and effort to become real entrepreneur. Prior study stat there is significant relation between nascent entrepreneur and Entrepreneurial Self Efficacy towards to venture a business. (Jeffrey et al., 2009) In this case, if a student has high self-efficacy, she/he will be more confident to searching for business opportunities and resources to expand their business bigger, to growing the business instead. As nascent entrepreneur, and have no business experience before, high self-efficacy is need to propose a business idea, turn the concept into reality, and look for new opportunities. With same knowledge given, with same method already gain during the study, it might had different result between high self-efficacy student with low self-efficacy student. This kind of self-efficacy usually called as passion. A passion which done with pressure and hard effort, a person will be enjoy to face any problem and uncertainty in business.

As a nascent entrepreneur, or called as newbie in business assumed has less than experience than medium enterprise owner, its normal when the result is self-efficacy as higher determinant in entrepreneurial intention. If the respondent is medium enterprise owner, had established business within 5 years minimum, it might be conclude different result.

In summary, as a nascent entrepreneur, as starter in entrepreneurial field, a person important to have high selfefficacy to search for business growth effort and opportunities. In longer term, it will affect the sustainability of our business too. Future, we look forward to seeing entrepreneurship researches gain insight on such momentum in the future about entrepreneurial intention in several class to gain more knowledge and current interpretation.

\section{REFERENCES}

[1] Adhitama. ANALISIS FAKTOR-FAKTOR YANG MEMPENGARUHI MINAT WIRAUSAHA DI KALANGAN MAHASISWA STUDI KASUS: FAKULTAS EKONOMI DAN BISNIS UNIVERSITAS MUHAMMADIYAH SURAKARTA. 2014;(Sancall):134-42.

[2] Gartner W, Liao J. The effects of perceptions of risk , environmental uncertainty, and growth aspirations on new venture creation success. 2012;703-12.

[3] Indarti N. Intensi Kewirausahaan Mahasiswa: Studi Perbandingan Antara Indonesia, Jepang dan Norwegia Intensi Kewirausahaan Mahasiswa: Studi Perbandingan Antara Indonesia , Jepang dan Norwegia. 2008;23(4):1-27.

[4] Ajzen I. The theory of planned behavior. Orgnizational Behav Hum Decis Process. 1991;50:179-211.

[5] Liñán F. Intention-based models of entrepreneurship education. Piccolla Impresa/Small Bus. 2004;3(January 2004):1-30.

[6] Suharti L. Faktor-Faktor yang Berpengaruh Terhadap Niat Kewirausahaan ( Entrepreneurial Intention ) ( Studi Terhadap Mahasiswa Universitas Kristen Satya Wacana, Salatiga ). 2011;

[7] Setiawan JL. Examining Entrepreneurial Self-efficacy among Students. Procedia - Soc Behav Sci [Internet]. 2014;115(Iicies 2013):235-42. Available from http://www.sciencedirect.com/science/article/pii/S187704281401979X

[8] Brockhaus RH. Risk taking propensity of entrepreneurs. Acad Manag J. 1980;23(3):509-20.

[9] Landqvist H, Stålhandske P. Risk propensity of entrepreneurs - A study of underlying factors in background and.

[10] Hung K-T, Tangpong C. General Risk Propensity in Multifaceted Business Decisions: Scale Development*. J Manag Issues [Internet]. 2010;22:7-8,88-106. Available from: http://search.proquest.com/docview/89213990?accountid=10297/nhttp:// sfx.cranfield.ac.uk/cranfield?url_ver=Z39.88-

2004\&rft_val_fmt=info:ofi/fmt:kev:mtx:journal\&genre=article\&sid=Pro Q:ProQ:abiglobal\&atitle=General+Risk+Propensity+in+Multifaceted+B usiness+De

[11] Koe W-L, Majid IA. A Model for Predicting Intention towards Sustainable Entrepreneurship. Int J Information, Bus Manag [Internet]. 2014;6(2):256-69. Available from: http://search.proquest.com/docview/1511120742?accountid=39066

[12] Jackson. Jackson Personality Inventory-Revised (JPI-R). 2011; 
[13] Liñán F, Rodríguez-Cohard JC, Rueda-Cantuche JM. Factors affecting entrepreneurial intention levels: A role for education. Int Entrep Manag J. 2011;7(2):195-218.

[14] Müller S. Encouraging Future Entrepreneurs: The Effect of Entrepreneurship Course Characteristics on Entrepreneurial Intention. 2008;(3550):289. Available from: https://www.alexandria.unisg.ch/publications/by-year/Y-2009/61106

[15] Capello PV, Ravasi D. The Variety and the Evolution of Business Models and Organizational Forms in the Italian Fashion Industry. Bus
Hist Conf Bus Econ Hist On-line Pap Present BHC Annu Meet [Internet]. 2009;7:1-19. Available from: http://search.proquest.com/docview/192406985?accountid=10755 \nhttp: //sfx.bib-bvb.de/sfx_uben?url_ver=Z39.88-

2004\&rft_val_fmt=info:ofi/fmt:kev:mtx:journal\&genre $=$ article $\&$ sid=Pro Q:ProQ:abiglobal\&atitle $=$ The + Variety + and + the + Evolution + of + Busines s+Models+and+Or 